IRA-International Journal of Applied Sciences ISSN 2455-4499; Vol.04, Issue 02 (2016)

Institute of Research Advances

Pg. no. 319-332

http://research-advances.org/index.php/IRAJAS

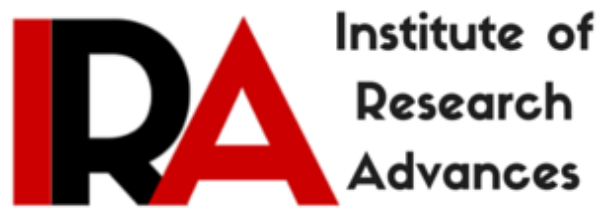

\title{
Study of gross alpha and gross beta activity concentration in sediment and soil samples of three southern districts of Tamil Nadu
}

\author{
${ }^{1}$ A. Priya Latha, ${ }^{2}$ G. Shanthi \\ 1,2 Department of Physics \& Research Centre, \\ Women's Christian College, Nagercoil, India.
}

Type of Review: Peer Reviewed.

DOI: http://dx.doi.org/10.21013/jas.v4.n2.p13

\section{How to cite this paper:}

Latha, A., \& Shanthi, G. (2016). Study of gross alpha and gross beta activity concentration in sediment and soil samples of three southern districts of Tamil Nadu. IRA-International Journal of Applied Sciences, 4(2), 319-332. doi:http://dx.doi.org/10.21013/jas.v4.n2.p13

(C) Institute of Research Advances (cc) EY-NC

This work is licensed under a Creative Commons Attribution-Non Commercial 4.0 International License subject to proper citation to the publication source of the work.

Disclaimer: The scholarly papers as reviewed and published by the Institute of Research Advances (IRA) are the views and opinions of their respective authors and are not the views or opinions of the IRA. The IRA disclaims of any harm or loss caused due to the published content to any party. 


\section{ABSTRACT}

Human can be exposed to the radiation emitting from different radioactive sources depending upon their activities and surroundings. Human activities have contributed to the increased concentration of some radionuclides in the environment. A survey of the gross alpha and gross beta activity in soil samples collected along the three southern districts of TamilNadu has been carried out. Determination of the gross alpha and gross beta activity concentration are done by using $\mathrm{ZnS}$ (Ag) and low beta counter. The gross alpha activity varies from $162.3 \mathrm{~Bq} / \mathrm{kg}$ to $3679.6 \mathrm{~Bq} / \mathrm{kg}$ near the sea and ranges from 107.5 $\mathrm{Bq} / \mathrm{kg}$ to $1774.1 \mathrm{~Bq} / \mathrm{kg} 150 \mathrm{~m}$ away from the sea. The gross alpha activity in the sub-urban area varies from $53.67 \mathrm{~Bq} / \mathrm{kg}$ to $644.12 \mathrm{~Bq} / \mathrm{kg}$. The gross beta activity concentration in the soil ranges from 388.8 $\mathrm{Bq} / \mathrm{kg}$ to $40111.1 \mathrm{~Bq} / \mathrm{kg}$ in the coastal region (near the sea) and ranges from $669.06 \mathrm{~Bq} / \mathrm{kg}$ tol3278.4 $B q / \mathrm{kg}$ (150 $\mathrm{m}$ away from the sea). While the gross beta activity concentration in the sub-urban area varies from $1103.05 \mathrm{~Bq} / \mathrm{kg}$ to $4202.12 \mathrm{~Bq} / \mathrm{kg}$. The obtained values shows soil from the sampled locations may pose some long time health hazards to the public. Statistical analysis are also performed between the soil samples.

Key words : Gross alpha, Gross beta, natural radioactivity, sediment, soil

\section{Introduction}

Naturally occurring radiation can be found all around us. Radiation can be found in soils, air, water, and in us. We encounter it every day through the food we eat, the water we drink, and the air we breathe also in building materials and items we commonly use. Human beings have been continuously exposed to ionizing and non-ionizing radiation. Both ionizing and non-ionizing radiation are harmful to organisms which result in changes to the natural environment. Radioactivity in nature comes from two main sources, terrestrial and cosmic. First there is the radiation in the soils and rocks, called primordial or terrestrial. Then there is radiation that comes from space, called cosmic or cosmogenic. Another source of exposure in the environment is the artificial source that are released from human activists such as radioactive fallout from past nuclear weapon testing and nuclear activities of nuclear research. The radiation that we are exposed come from two sources, that which occur naturally and that which is due to the activities of man. Natural environmental radioactivity arises mainly from primordial radionuclides, such as ${ }^{40} \mathrm{~K}$ and the nuclides from the ${ }^{232} \mathrm{Th}$ and ${ }^{238} \mathrm{U}$ series and their decay products. The decay of naturally occurring radionuclides in soil produces exposures to humans. The radioactivity measurement is significant to assess the radiation impact on environment, population exposed to radiation. The worldwide average background dose to humans is about $2.4 \mathrm{mSv} / \mathrm{year}$ [1]. The dose from these sources varies in different parts of the world. The concentration of natural radioactivity and the associated external exposure vary depend on the geological and geographical conditions in the soils of each region in the world [2]. Irradiation of the human body from external sources is mainly by gamma radiation from radionuclides of the ${ }^{235} \mathrm{U},{ }^{238} \mathrm{U}$ and ${ }^{232} \mathrm{Th}$ decay series and from ${ }^{40} \mathrm{~K}$. These radionuclides may be present in the body and irradiate various organs with alpha and beta particles as well as gamma rays. Alpha radiation travels a very short distance through air. The nucleus is initially in an unstable energy state. An internal change takes place in the unstable nucleus and an alpha particle is ejected leaving a decay product. The atom has then lost two protons along with two neutrons. Alpha-emitting materials can be harmful to humans if the materials are inhaled, swallowed, or absorbed through open wounds. A fast-moving electron or positron that is emitted from a nucleus during the radioactive process known as beta decay. Large amounts of beta radiation may cause skin burns, and beta emitters are harmful if they enter the body. Beta particles may be stopped by thin sheets of metal or plastic. Beta particles travel with an initial speed of about 180 million m/s. A medium energy beta particle will travel about one meter in air but only about one millimeter through body tissue. Potassium-40 and carbon-14 are weak beta emitters that are found naturally in our bodies. Some decay products of radon emit beta particles. Beta emitters that eject energetic particles can pose a significant health concern. The radiation hazard from beta particle is 
greatest if they are ingested. Naturally occurring radionuclides are the largest contributors to radiation doses received by human beings. Measurements of natural radioactivity in soil have been performed throughout the world [3-8]. The soil radioactivity is usually important to establish baseline data for futuristic purpose of radiation assessment and protection. The present work investigates the gross alpha and gross beta activity concentration in soil samples collected from different locations of south east region of Tamilnadu.

\section{Experimental}

\section{Sample collection}

The samples are collected from the three southern districts of Tamil Nadu ( Kanyakumari, Tirunelveli, and Tuticorin). The locations surveyed in the present work are shown in map. The study area lie between latitudes $8^{\circ} 29^{\prime}$ to $8^{\circ} 48^{\prime} \mathrm{N}$ and longitude $78^{\circ} 11^{\prime}$ to $78^{\circ} 29^{\prime} \mathrm{E}$. A total of 30 soil samples are collected from the both low and high background radiation areas which is from various distance (near the sea, $150 \mathrm{~m}$ away from the sea, sub-urban area). The samples are collected at a depth of $10 \mathrm{~cm}$ from every site. The samples are crushed to a fine powder, dried until the moisture of the soil is removed completely and are properly sealed, coded according to the location. Three different sizes of sieve are used for sieving the samples which are $0.250 \mathrm{~mm}, 0.063 \mathrm{~mm}$ and $0.025 \mathrm{~mm}$ respectively. The samples are kept in room temperature for a month to reach secular equilibrium between ${ }^{226} \mathrm{Ra}$ and its daughters.

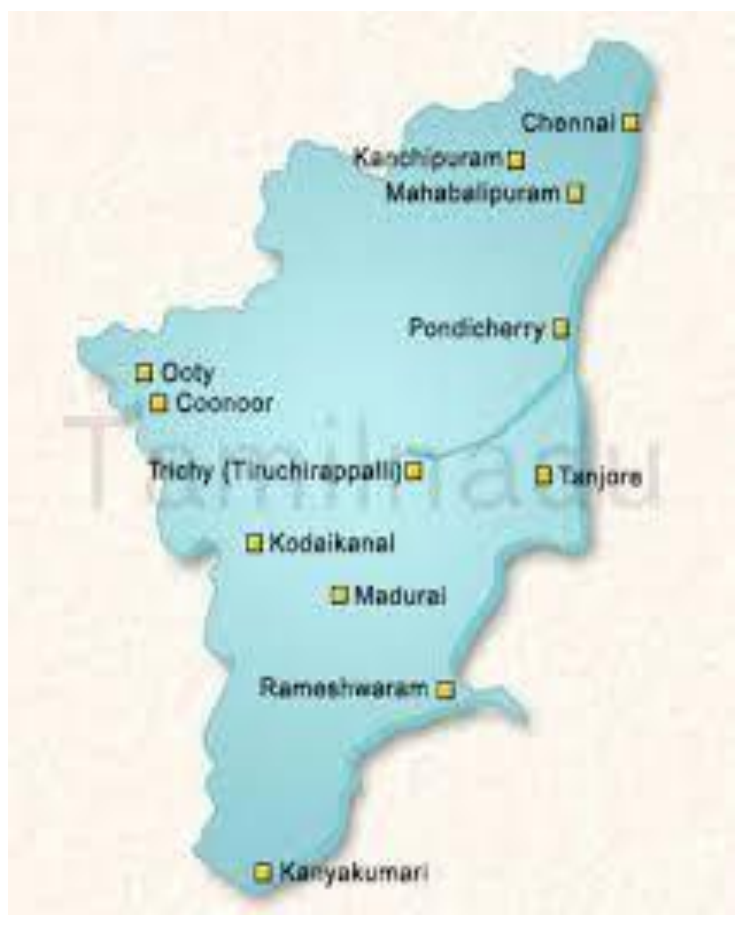

Sample preparation

The measurement of the gross alpha and gross beta activity in the samples is carried out by using Alpha Probe AP185 radiation counting system and Beta Counting System BCS 36A, Electronics Corporation of India Limited. In order to measure the concentration of gross alpha and gross beta activity 
in the collected samples, each soil sample weighing $0.06 \mathrm{gm}$ is taken and powdered with the help of agate motor and uniformly spread on the aluminium planchet. The sample is counted for a time period of 1000 s. The net counts obtained are found out by subtracting the background count from the sample counts and thus the gross beta activity can be calculated. As mentioned above, similar procedure is applied to determine the background count.

\section{Results and discussions}

Table [1-3] shows the summary of results of the gross alpha and gross beta activity of the selected soil samples near the sea of sieve size $0.250 \mathrm{~mm}, 0.063 \mathrm{~mm}$ and $0.025 \mathrm{~mm}$. The gross alpha and beta radioactivity concentration of the collected soil samples $150 \mathrm{~m}$ away from the sea are presented in table [4-6]. Soil samples are analyzed for gross alpha and gross beta activity. As shown in the table 1, the alpha activity concentration varies from $216.4 \mathrm{~Bq} / \mathrm{kg}$ to $3679.6 \mathrm{~Bq} / \mathrm{kg}$ and beta activity concentration ranges from $388.8 \mathrm{~Bq} / \mathrm{kg}$ to $40111.1 \mathrm{~Bq} / \mathrm{kg}$ near the sea of sieve size $0.250 \mathrm{~mm}$. In table 2, the alpha activity concentration varies from $270.5 \mathrm{~Bq} / \mathrm{kg}$ to $3517.3 \mathrm{~Bq} / \mathrm{kg}$ and beta activity concentration varies from 1777.7 Bq/kg to $24166.6 \mathrm{~Bq} / \mathrm{kg}$ in the coastal region (neat the sea) of sieve size $0.063 \mathrm{~mm}$. According to table 3, the maximum alpha and beta activity is observed in Ko1 of sieve size $0.025 \mathrm{~mm}$. As seen in table 4, the sample Pml5 shows maximum alpha and beta activity of $1774.1 \mathrm{~Bq} / \mathrm{kg}$ and $12512.8 \mathrm{~Bq} / \mathrm{kg}(150 \mathrm{~m}$ away from the sea) of sieve size $0.250 \mathrm{~mm}$. In table 5, the alpha activity is higher in Pml5 where the gross beta activity is higher in Uv5 of sieve size $0.063 \mathrm{~mm}$. Table 6 shows that the sample Uv5 shows maximum alpha activity and the sample Pml5 shows maximum beta activity in the coastal region of sieve size $0.025 \mathrm{~mm}$. In table 7, the sample Ti shows higher alpha and beta activity in the sub-urban area of sieve size $0.250 \mathrm{~mm}$. In tables 8 and 9, the maximum alpha and beta activity is observed in sample $\mathrm{Ku}$ and $\mathrm{Ni}$ in the sub-urban area of sieve size $0.063 \mathrm{~mm}$ and Ni sample shows higher alpha and beta activity concentration of sieve size $0.025 \mathrm{~mm}$ compared with other region. The maximum alpha activity is due to the presence of uranium and radium isotopes in the corresponding region. The elevation of the gross beta activity of the study are could be attributed to the highest potassium content present in the sample. Table [10-15] shows ANOVA result of soil samples in coastal region and sub-urban area of sieve size 0.250 $\mathrm{mm}, 0.063 \mathrm{~mm}$ and $0.025 \mathrm{~mm}$ respectively. The correlation analysis has been carried out to determine the mutual relationship and the strength of association between the samples of various sieve size. Strong correlation is observed between the samples of sieve size $0.250 \mathrm{~mm}$ and $0.025 \mathrm{~mm}$ in the coastal region $(\mathrm{r}$ $=0.97)$. Negative correlation is found between the sample sieve size $0.250 \mathrm{~mm}$ and $0.025 \mathrm{~mm}(\mathrm{r}=-0.12)$. The results are then evaluated by a one-way analysis of variance. Statistical significance is assessed at the $\mathrm{p}<0.05$ probability level. This means the results do not differ significantly. Figure [1-9] shows the gross alpha and beta activity concentration for the soil samples of sieve size $0.250 \mathrm{~mm}, 0.063 \mathrm{~mm}$ and 0.025 $\mathrm{mm}$ near the sea, $150 \mathrm{~m}$ away from the sea and in the sub-urban area.

\section{Conclusion}

The results of this investigation for the soil samples along the south eastern coast of Tamil Nadu are summarized in Table [1-15]. The gross alpha and beta activity measurements for the collected samples is achieved by using alpha and beta counting system. The maximum gross alpha and beta activity is observed in Ko1 sample in the coastal region of sieve size $0.250 \mathrm{~mm}$. The higher alpha activity concentration in the soil sample is due to the presence of high radioactive content in the sample. Ku sample in the sub-urban area shows maximum alpha activity of sieve size $0.025 \mathrm{~mm}$. Ni soil sample of sieve size $0.063 \mathrm{~mm}$ exhibit higher beta activity compared with other region in the sub-urban area. The alpha and beta activity concentration shows large variations in all the locations. According to the results obtained in this study, it can be concluded the maximum alpha activity is due to the existence of uranium and radium isotopes in the sample and maximum beta activity is due to the highest potassium content 
present in the sample. The positive correlation coefficient is observed between the sample sieve size 0.250 $\mathrm{mm}$ and $0.025 \mathrm{~mm}$ in the coastal region.

Table 1 . The gross alpha and gross beta activity in the soil samples near the sea for sieve size $0.250 \mathrm{~mm}$

\begin{tabular}{|l|l|l|}
\hline Sampling Location & $\alpha(\mathrm{Bq} / \mathrm{kg})$ & $\beta(\mathrm{Bq} / \mathrm{kg})$ \\
\hline Ko1 & 3679.6 & 40111.1 \\
\hline Le1 & 1515.1 & 7388.8 \\
\hline Uv1 & 1190.4 & 7444.4 \\
\hline Pe1 & 1569.2 & 12722.2 \\
\hline Ma1 & 595.2 & 1388.8 \\
\hline Aa1 & 216.4 & 388.8 \\
\hline Th1 & 378.7 & 2944.2 \\
\hline Ve1 & 216.4 & 1722.2 \\
\hline Pml1 & 703.4 & 3944.4 \\
\hline Mtm1 & 270.5 & 2166.6 \\
\hline
\end{tabular}

Table 2. The gross alpha and gross beta activity in the soil samples near the sea for sieve size $0.063 \mathrm{~mm}$

\begin{tabular}{|l|l|l|}
\hline Sampling Location & $\alpha(\mathrm{Bq} / \mathrm{kg})$ & $\beta(\mathrm{Bq} / \mathrm{kg})$ \\
\hline Ko1 & 3517.3 & 24166.6 \\
\hline Le1 & 2435.0 & 16777.7 \\
\hline Uv1 & 1731.6 & 18777.7 \\
\hline Pe1 & 1893.9 & 13555.5 \\
\hline Ma1 & 270.5 & 1777.7 \\
\hline Aa1 & 270.5 & 2277.7 \\
\hline Th1 & 1785.7 & 12388.8 \\
\hline Ve1 & 378.7 & 3055.5 \\
\hline Pml1 & 1569.2 & 6555.5 \\
\hline Mtm1 & 378.7 & 2611.1 \\
\hline
\end{tabular}

Table 3. The gross alpha and gross beta activity in the soil samples near the sea for sieve size $0.025 \mathrm{~mm}$

\begin{tabular}{|l|l|l|}
\hline Sampling Location & $\alpha(\mathrm{Bq} / \mathrm{kg})$ & $\beta(\mathrm{Bq} / \mathrm{kg})$ \\
\hline Ko1 & 3354.9 & 30888.8 \\
\hline Le1 & 1461.0 & 8555.5 \\
\hline Uv1 & 1352.8 & 10833.3 \\
\hline Pe1 & 2759.7 & 14833.3 \\
\hline Ma1 & 162.3 & 1333.3 \\
\hline Aa1 & 162.3 & 1055.5 \\
\hline Th1 & 703.4 & 5722.2 \\
\hline Ve1 & 487.0 & 1500.0 \\
\hline Pml1 & 1298.7 & 6000.0 \\
\hline Mtm1 & 270.5 & 3111.1 \\
\hline
\end{tabular}


Table 4. The gross alpha and gross beta activity in the soil samples $150 \mathrm{~m}$ the sea for sieve size $0.250 \mathrm{~mm}$

\begin{tabular}{|l|l|l|}
\hline Sampling Location & $\alpha(\mathrm{Bq} / \mathrm{kg})$ & $\beta(\mathrm{Bq} / \mathrm{kg})$ \\
\hline Ko5 & 537.6 & 1749.8 \\
\hline Le5 & 860.2 & 5352.5 \\
\hline Uv5 & 1344.4 & 5301.0 \\
\hline Pe5 & 376.3 & 669.06 \\
\hline Ma5 & 967.7 & 4992.2 \\
\hline Aa5 & 483.8 & 1384.6 \\
\hline Th5 & 215.0 & 2769.2 \\
\hline Ve5 & 430.1 & 2358.9 \\
\hline Pm15 & 1774.1 & 12512.8 \\
\hline Mtm5 & 268.8 & 1333.3 \\
\hline
\end{tabular}

Table 5. The gross alpha and gross beta activity in the soil samples $150 \mathrm{~m}$ the sea for sieve size $0.063 \mathrm{~mm}$

\begin{tabular}{|l|l|l|}
\hline Sampling Location & $\alpha(\mathrm{Bq} / \mathrm{kg})$ & $\beta(\mathrm{Bq} / \mathrm{kg})$ \\
\hline Ko5 & 591.3 & 2779.2 \\
\hline Le5 & 752.6 & 6381.8 \\
\hline Uv5 & 1397.8 & 13278.4 \\
\hline Pe5 & 215.0 & 2624.8 \\
\hline Ma5 & 752.6 & 10910.9 \\
\hline Aa5 & 709.6 & 6666.6 \\
\hline Th5 & 537.6 & 2871.7 \\
\hline Ve5 & 967.7 & 7948.7 \\
\hline Pm15 & 1505.3 & 7846.1 \\
\hline Mtm5 & 322.5 & 1897.4 \\
\hline
\end{tabular}

Table 6 . The gross alpha and gross beta activity in the soil samples $150 \mathrm{~m}$ the sea for sieve size $0.025 \mathrm{~mm}$

\begin{tabular}{|l|l|l|}
\hline Sampling Location & $\alpha(\mathrm{Bq} / \mathrm{kg})$ & $\beta(\mathrm{Bq} / \mathrm{kg})$ \\
\hline Ko5 & 430.1 & 2882.1 \\
\hline Le5 & 268.8 & 3602.6 \\
\hline Uv5 & 967.7 & 7205.3 \\
\hline Pe5 & 107.5 & 1286.6 \\
\hline Ma5 & 645.1 & 4014.4 \\
\hline Aa5 & 268.8 & 3846.1 \\
\hline Th5 & 430.1 & 3589.7 \\
\hline Ve5 & 537.6 & 3282.0 \\
\hline Pm15 & 860.2 & 7897.4 \\
\hline Mtm5 & 376.3 & 1179.4 \\
\hline
\end{tabular}

Table 7. The gross alpha and gross beta activity in the soil samples in the sub-urban area for sieve size $0.250 \mathrm{~mm}$

\begin{tabular}{|l|l|l|}
\hline Sampling Location & $\alpha(\mathrm{Bq} / \mathrm{kg})$ & $\beta(\mathrm{Bq} / \mathrm{kg})$ \\
\hline $\mathrm{Vm}$ & 268.38 & 2468.74 \\
\hline $\mathrm{Ku}$ & 322.06 & 2416.22 \\
\hline
\end{tabular}




\begin{tabular}{|l|l|l|}
\hline $\mathrm{Vr}$ & 429.41 & 2206.11 \\
\hline $\mathrm{Ni}$ & 268.38 & 2153.58 \\
\hline $\mathrm{Mu}$ & 375.73 & 2836.43 \\
\hline $\mathrm{Pi}$ & 375.73 & 1943.48 \\
\hline $\mathrm{Vlu}$ & 214.70 & 2521.27 \\
\hline $\mathrm{Vam}$ & 53.67 & 1103.05 \\
\hline $\mathrm{Mlm}$ & 322.06 & 1680.84 \\
\hline $\mathrm{Ti}$ & 483.09 & 3046.53 \\
\hline
\end{tabular}

Table 8. The gross alpha and gross beta activity in the soil samples in the sub-urban area for sieve size $0.063 \mathrm{~mm}$

\begin{tabular}{|l|l|l|}
\hline Sampling Location & $\alpha(\mathrm{Bq} / \mathrm{kg})$ & $\beta(\mathrm{Bq} / \mathrm{kg})$ \\
\hline $\mathrm{Vm}$ & 268.38 & 2783.90 \\
\hline $\mathrm{Ku}$ & 590.44 & 1996.00 \\
\hline $\mathrm{Vr}$ & 322.06 & 2468.74 \\
\hline $\mathrm{Ni}$ & 268.38 & 4202.12 \\
\hline $\mathrm{Mu}$ & 483.09 & 1365.68 \\
\hline $\mathrm{Pi}$ & 375.73 & 2258.64 \\
\hline $\mathrm{Vlu}$ & 161.03 & 1733.37 \\
\hline $\mathrm{Vam}$ & 322.06 & 1838.42 \\
\hline $\mathrm{Mlm}$ & 214.70 & 2311.16 \\
\hline $\mathrm{Ti}$ & 375.73 & 2678.85 \\
\hline
\end{tabular}

Table 9. The gross alpha and gross beta activity in the soil samples in the sub-urban area for sieve size $0.025 \mathrm{~mm}$

\begin{tabular}{|l|l|l|}
\hline Sampling Location & $\alpha(\mathrm{Bq} / \mathrm{kg})$ & $\beta(\mathrm{Bq} / \mathrm{kg})$ \\
\hline $\mathrm{Vm}$ & 536.76 & 2573.79 \\
\hline $\mathrm{Ku}$ & 644.12 & 3519.27 \\
\hline $\mathrm{Vr}$ & 322.06 & 3256.64 \\
\hline $\mathrm{Ni}$ & 161.03 & 2153.58 \\
\hline $\mathrm{Mu}$ & 161.03 & 1575.79 \\
\hline $\mathrm{Pi}$ & 322.06 & 2468.74 \\
\hline $\mathrm{Vlu}$ & 322.06 & 2048.53 \\
\hline $\mathrm{Vam}$ & 107.35 & 2573.79 \\
\hline $\mathrm{Mlm}$ & 161.03 & 1628.32 \\
\hline $\mathrm{Ti}$ & 483.09 & 2101.06 \\
\hline
\end{tabular}

Table 10. ANOVA result of gross alpha activity for soil samples near the sea

\begin{tabular}{|l|l|l|l|l|l|l|}
\hline Source & SS & df & MS & F & p-value & F-critical \\
\hline Between groups & 763893 & 2 & 381946.5 & 0.3236 & 0.7262 & 3.3541 \\
Within groups & 31860512.12 & 27 & 1180018.96 & & & \\
\hline Total & 32624405 & 29 & & & & \\
\hline
\end{tabular}


Table 11. ANOVA result of gross alpha activity for soil samples $150 \mathrm{~m}$ from the sea

\begin{tabular}{|l|l|l|l|l|l|l|}
\hline Source & SS & df & MS & F & p-value & F-critical \\
\hline Between groups & 467316.72 & 2 & 233658.36 & 1.3836 & 0.2678 & 3.3541 \\
Within groups & 4559437.49 & 27 & 168868.05 & & & \\
\hline Total & 5026754 & 29 & & & & \\
\hline
\end{tabular}

Table 12. ANOVA result of gross alpha activity for soil samples in the sub-urban area

\begin{tabular}{|l|l|l|l|l|l|l|}
\hline Source & SS & df & MS & F & p-value & F-critical \\
\hline Between groups & 3649.811 & 2 & 1824.905 & 0.085639 & 0.918174 & 3.354131 \\
Within groups & 575348.9 & 27 & 21309.22 & & & \\
\hline Total & 578998.7 & 29 & & & & \\
\hline
\end{tabular}

Table 13. ANOVA result of gross beta activity for soil samples near the sea

\begin{tabular}{|l|l|l|l|l|l|l|}
\hline Source & SS & df & MS & F & p-value & F-critical \\
\hline Between groups & 27096744 & 2 & 13548372 & 0.1406 & 0.8693 & 3.3541 \\
Within groups & $2.6 \mathrm{E}+09$ & 27 & 96304788 & & & \\
\hline Total & $2.63 \mathrm{E}+09$ & 29 & & & & \\
\hline
\end{tabular}

Table 14. ANOVA result of gross beta activity for soil samples $150 \mathrm{~m}$ from the sea

\begin{tabular}{|l|l|l|l|l|l|l|}
\hline Source & SS & df & MS & F & p-value & F-critical \\
\hline Between groups & 40354235 & 2 & 20177117 & 1.9045 & 0.1683 & 3.3541 \\
Within groups & $2.86 \mathrm{E}+08$ & 27 & 10593958 & & & \\
\hline Total & $3.26 \mathrm{E}+08$ & 29 & & & & \\
\hline
\end{tabular}


Table 15. ANOVA result of gross beta activity for soil samples in the sub-urban area

\begin{tabular}{|l|l|l|l|l|l|l|}
\hline Source & SS & df & MS & F & p-value & F-critical \\
\hline Between groups & 132616.1 & 2 & 66308.06 & 0.1497 & 0.8616 & 3.3541 \\
Within groups & 11954647 & 27 & 442764.7 & & & \\
\hline Total & 12087263 & 29 & & & & \\
\hline
\end{tabular}

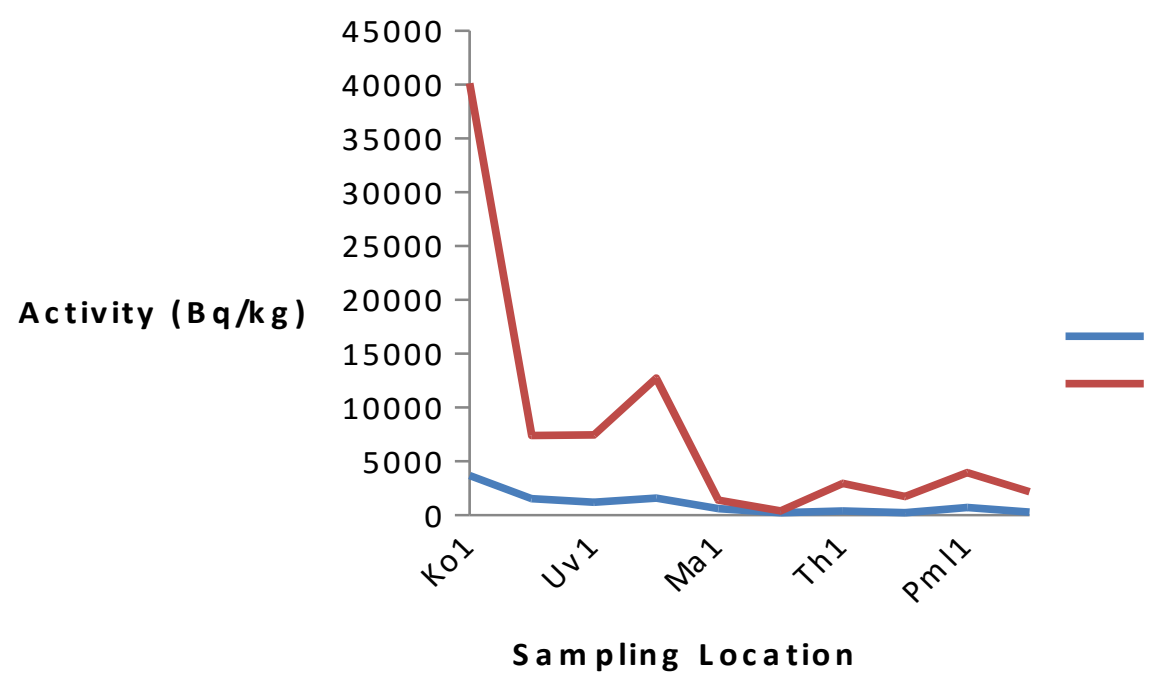

Fig 1. The gross alpha and beta activity concentration of soil samples near the sea of sieve size $0.250 \mathrm{~mm}$

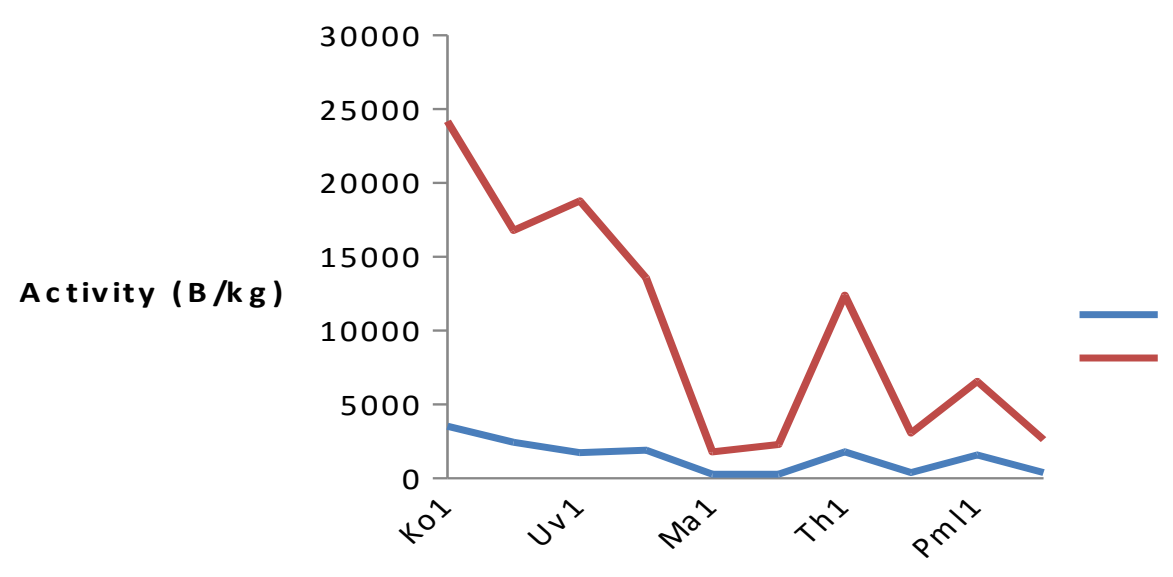

Sampling Location

Fig 2. The gross alpha and beta activity concentration of soil samples near the sea of sieve size $0.063 \mathrm{~mm}$ 


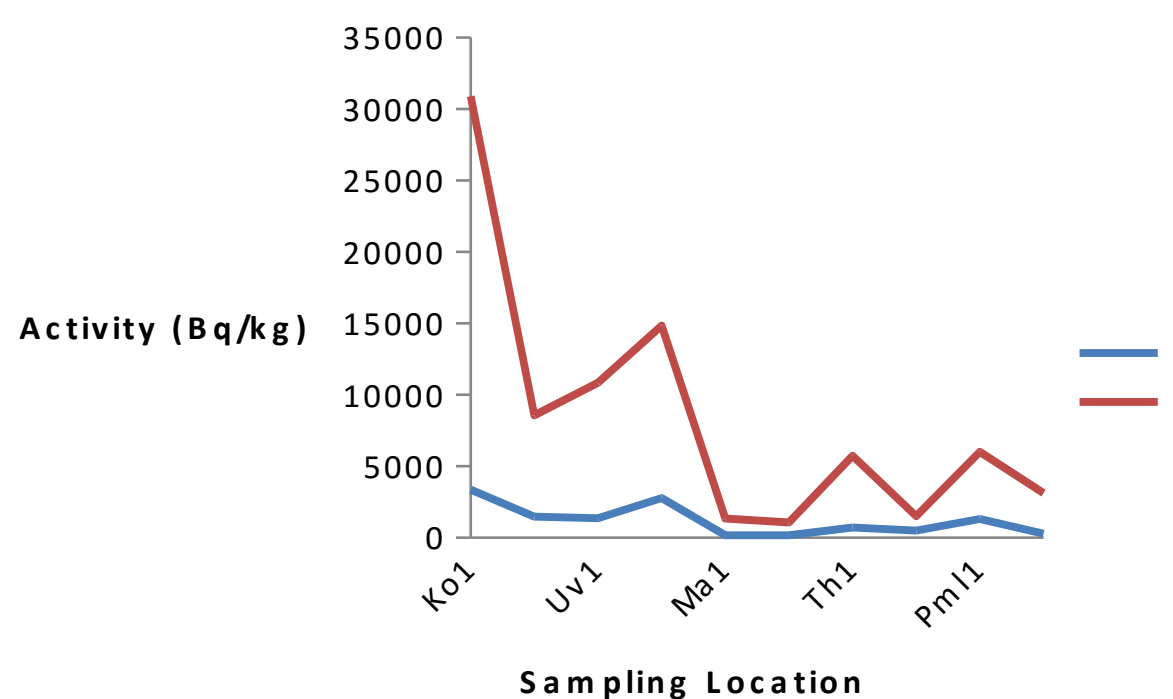

Fig 3. The gross alpha and beta activity concentration of soil samples near the sea of sieve size $0.025 \mathrm{~mm}$

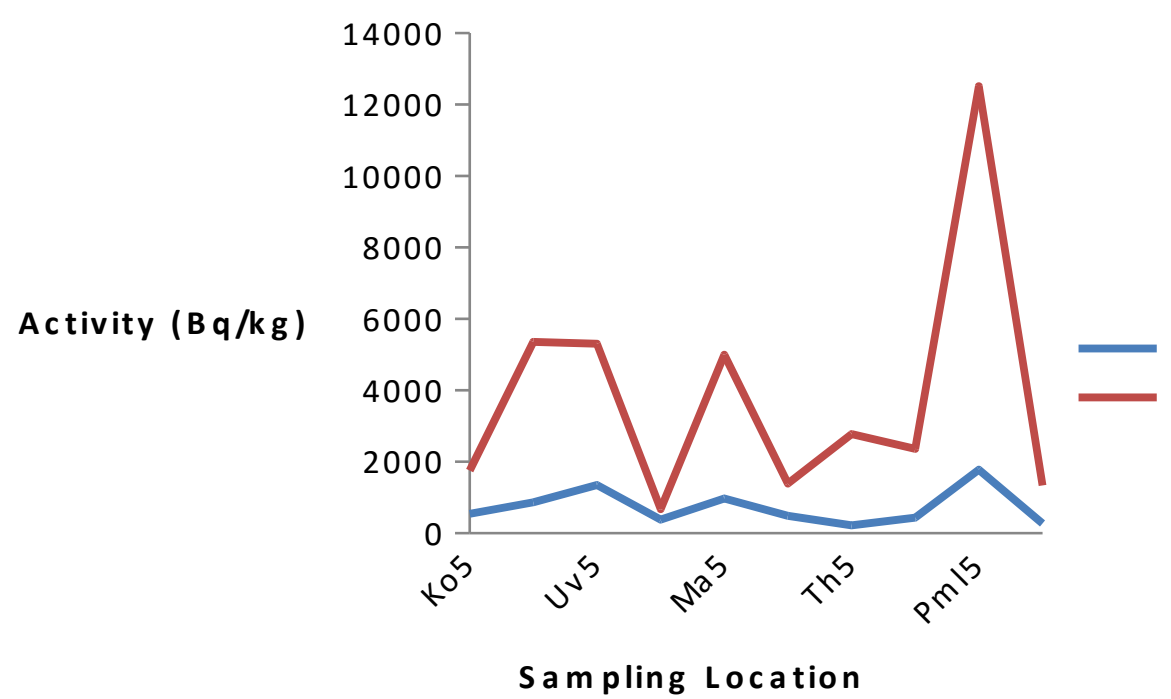

Fig 4. The gross alpha and beta activity concentration of soil samples $150 \mathrm{~m}$ away from the sea of sieve size $0.250 \mathrm{~mm}$ 


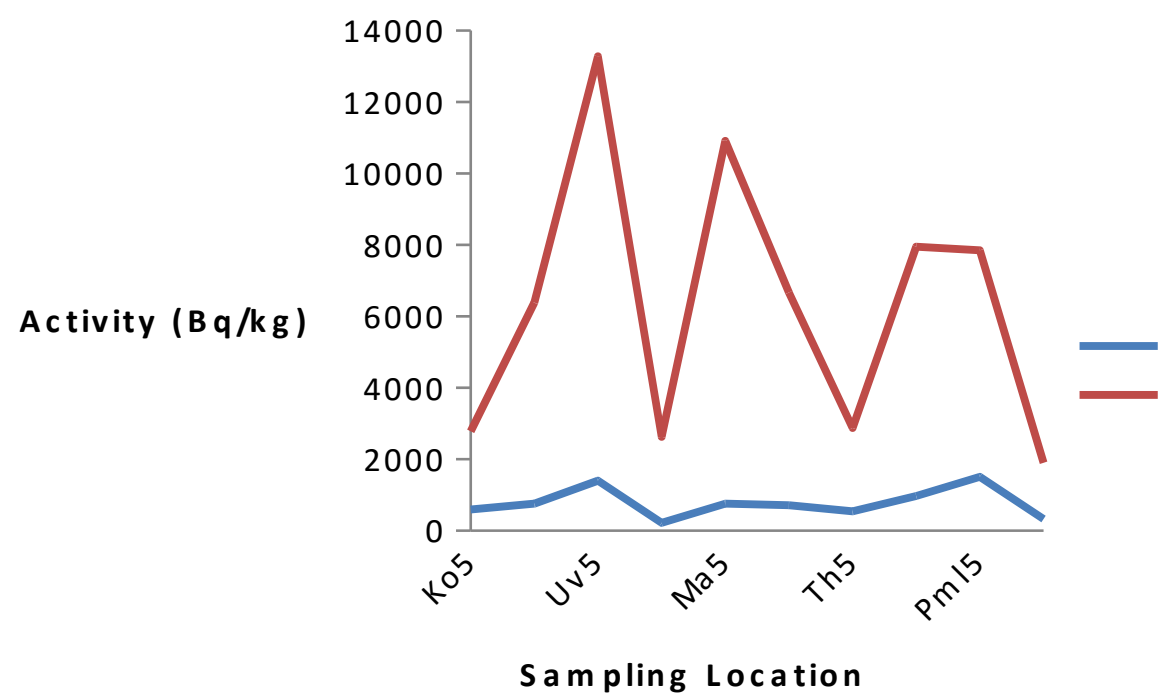

Fig 5. The gross alpha and beta activity concentration of soil samples $150 \mathrm{~m}$ away from the sea of sieve size $0.063 \mathrm{~mm}$

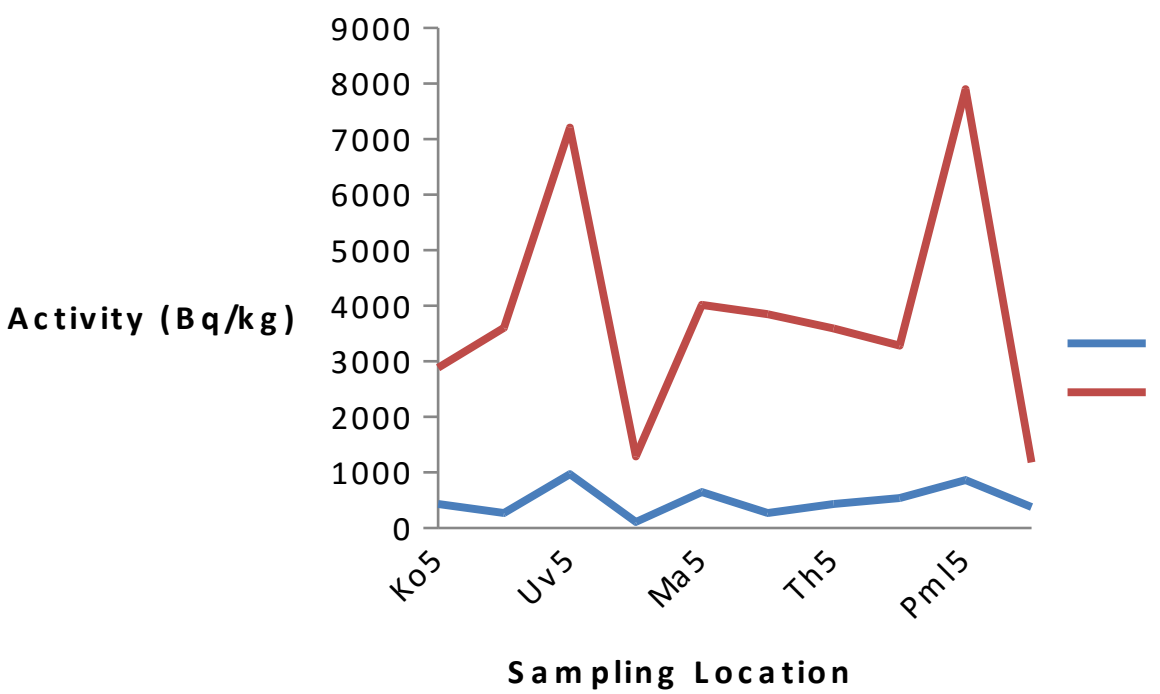

Fig 6. The gross alpha and beta activity concentration of soil samples $150 \mathrm{~m}$ away from the sea of sieve size $0.025 \mathrm{~mm}$ 


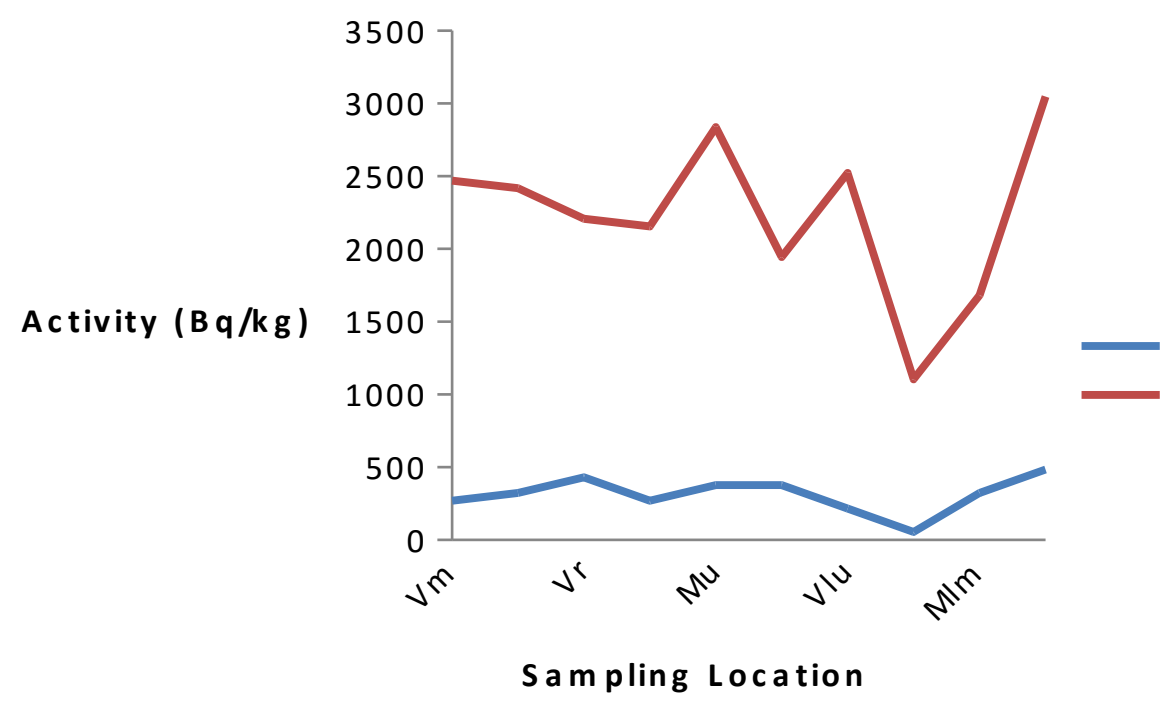

Fig 7. The gross alpha and beta activity concentration of soil samples in the sub-urban area of sieve size $0.250 \mathrm{~mm}$

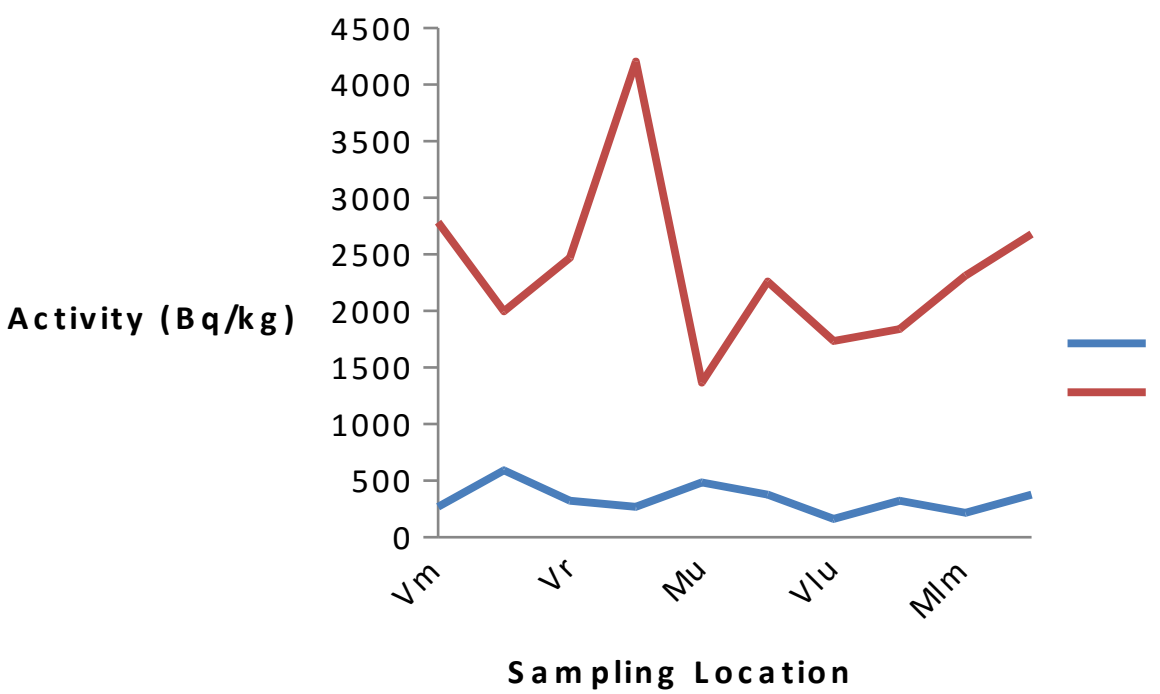

Fig 8. The gross alpha and beta activity concentration of soil samples in the sub-urban area of sieve size $0.063 \mathrm{~mm}$ 


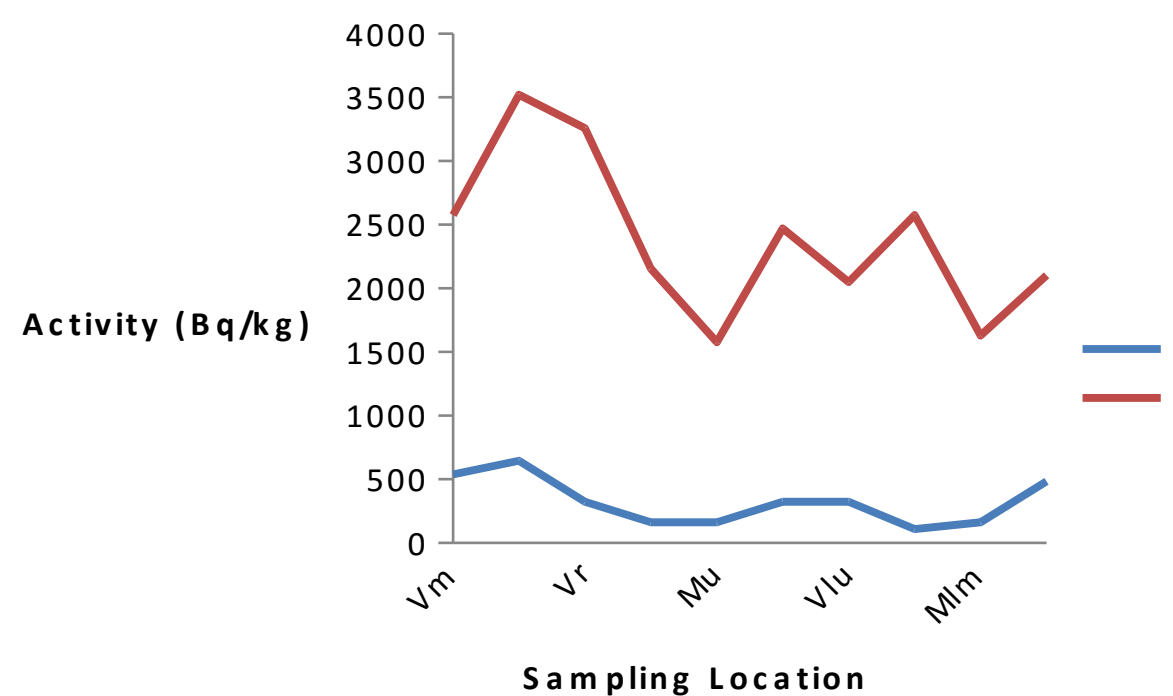

Fig 9. The gross alpha and beta activity concentration of soil samples in the sub-urban area of sieve size $0.250 \mathrm{~mm}$

\section{References}

[1] United Nations Scientific Committee on the Effects of Atomic Radiation, 2008. Sources and effects of ionizing radiation, United Nations. New York, 4, ISBN 978-92-1-142274-0.

[2] United Nations Scientific Committee on the Effects of Atomic Radiation, 2000. Effects and risks of ionizing radiations, United Nations, New York.

[3] Khondaker Mohammed Nazrul Islam, Debasish Paul, Md. Mahbubur Rahman Bhuiyan, Amina Akter, Budrun Neher, Sheikh Mohammad Azharul Islam. Study of Environmental Radiation on Sand and Soil Samples from Kuakata Sea Beach of Patuakhali, 2012. Journal of Environmental Protection, 3, 10781084.

[4] Harb S., Natural Radioactivity and External Gamma Radiation Exposure at The Costal Red Sea in Egypt,2008. Radiation Protection Dosimetry Vol 130, No 3, pp. 376-384.

[5] Kannan, V., Rajan, M.P., Lyengar, M.A. and Ramesh, R. Distribution of natural and anthropogenic radionuclides in soil and beach sand Samples of Kalpakkam (India). Appl. Rodiat. Isot. 57,109-119 (2002).

[6] Saad, H. R. and Al-Azmi, D. Radioactivity concentrations in sediments and their correlation to the coastal structure in Kuwait. Applied Radiation and Isotopes, 2002. 56, 991-997.

[7] Suresh, G., Ramasamy, V., Meenakshisundaram, V., Venkatachalapathy, R. and Ponnusamy, V. Influence of mineralogical and heavy metal composition on natural radionuclide concentrations in the river sediments, 2011. Applied Radiation and Isotopes, 69, 1466-1474. 
[8] Khatir, S. A., Ahamed, M.O., El-Khangi, F.A., Nigumi, Y.O. and Holm, E. Radioactivity levels in the Red Sea coastal environment of Sudan, 1998. Marine Pollution Bulletin, 36 , 19-26.

[9] Arogunjo, A.M., Farai, I.P. and Fuwape, I.A. Dose rate assessment of terrestrial gamma radiation in the delta region of Nigeria. 2004. Radiation Protection Dosimetry, 108, 73-77. 